\title{
Article \\ Evaluation of Antibiotic Tolerance in Pseudomonas aeruginosa for Aminoglycosides and Its Predicted Gene Regulations through In-Silico Transcriptomic Analysis
}

\author{
Abishek Kumar B ${ }^{1, *}\left(\mathbb{D}\right.$, Bency Thankappan ${ }^{2}$, Angayarkanni Jayaraman ${ }^{2, *}$ and Akshita Gupta ${ }^{1}$ (I) \\ 1 Department of Microbiology, Kasturba Medical College (Manipal), Manipal Academy of Higher \\ Education (MAHE), Manipal 576104, India; akshitagupta1412@gmail.com \\ 2 Department of Microbial Biotechnology, Bharathiar University, Coimbatore 641046, India; \\ benzbt11@gmail.com \\ * Correspondence: abishek77@hotmail.com (A.K.B.); angaibiotech@buc.edu.in (A.J.); \\ Tel.: +91-801-521-6350 or +91-908-031-0146 (A.K.B.)
}

Citation: Kumar B, A.; Thankappan, B.; Jayaraman, A.; Gupta, A. Evaluation of Antibiotic Tolerance in Pseudomonas aeruginosa for Aminoglycosides and Its Predicted Gene Regulations through In-Silico Transcriptomic Analysis. Microbiol. Res. 2021, 12, 630-645. https:// doi.org/10.3390/microbiolres12030045

Academic Editors: Juan M. Tomás and Maria Teresa

Ceccherini Guicciardini

Received: 1 May 2021

Accepted: 20 July 2021

Published: 29 July 2021

Publisher's Note: MDPI stays neutral with regard to jurisdictional claims in published maps and institutional affiliations.

Copyright: (c) 2021 by the authors. Licensee MDPI, Basel, Switzerland. This article is an open access article distributed under the terms and conditions of the Creative Commons Attribution (CC BY) license (https:// creativecommons.org/licenses/by/ $4.0 /)$

\begin{abstract}
Pseudomonas aeruginosa causes chronic infections, such as cystic fibrosis, endocarditis, bacteremia, and sepsis, which are life-threatening and difficult to treat. The lack of antibiotic response in P. aeruginosa is due to adaptive resistance mechanism, which prevents the entry of antibiotics into the cytosol of the cell to achieve tolerance. Among the different groups of antibiotics, aminoglycosides are used as a parenteral antibiotic for the treatment of $P$. aeruginosa. This study aimed to determine the kinetics of antibiotic tolerance and gene expression changes in $P$. aeruginosa exposed to amikacin, gentamicin, and tobramycin. These antibiotics were exposed to $P$. aeruginosa at their MICs and the experimental setup was monitored for $72 \mathrm{~h}$, followed by the measurement of optical density every $12 \mathrm{~h}$. The growth of P. aeruginosa in the MICs of antibiotics represented the kinetics of antibiotic tolerance in amikacin, gentamicin, and tobramycin. The transcriptomic profile of antibiotic exposed P. aeruginosa PA14 was taken from the Gene Expression Omnibus (GEO), NCBI as microarray datasets. The gene expressions of two datasets were compared by test versus control. Tobramycin-exposed P. aeruginosa failed to develop tolerance in MICs of $0.5 \mu \mathrm{g} / \mathrm{mL}, 1 \mu \mathrm{g} / \mathrm{mL}$, and $1.5 \mu \mathrm{g} / \mathrm{mL}$, whereas amikacin- and gentamicin-treated P. aeruginosa developed tolerance. This illustrated the superior in vitro response of tobramycin over gentamicin and amikacin. Further, in silico transcriptomic analysis of tobramycin-treated $P$. aeruginosa resulted in differentially expressed genes (DEGs), enriched in 16s rRNA methyltransferase E, B, and L, alginate biosynthesis genes, and several proteins of the type II secretion system (T2SS) and type III secretion system (T3SS). The regulation of $m u c A$ in alginate biosynthesis, and gidB in RNA methyltransferases, suggested an increased antibiotic response and a low probability of developing resistance during tobramycin treatment. The use of tobramycin as a parenteral antibiotic with its synergistic combination might combat $P$. aeruginosa with increased response.
\end{abstract}

Keywords: adaptive resistance; antibiotic tolerance; in vitro exposure; aminoglycoside; Pseudomonas aeruginosa; differentially expressed genes (DEGs); transcriptomic analysis

\section{Introduction}

P. aeruginosa is an opportunistic pathogen, which causes chronic infections that are difficult to treat due to its limited response to antimicrobials and the emergence of antibiotic resistance during therapy [1]. Multi-drug resistance (MDR) is increasing due to overexposure to antibiotics [2]. Drug resistance in P. aeruginosa is developed as a result of various physiological and genetic mechanisms, which include multidrug efflux pumps, beta-lactamase production, outer membrane protein (porin) loss, and target mutations. In hospitals, MDR P. aeruginosa are, in most cases, concurrently resistant to ciprofloxacin, imipenem, ceftazidime, and piperacillin-tazobactam, which limits treatment options [3]. 
Aminoglycosides are a major group of antibiotics with a potential bacteriocidic effect for the treatment of Pseudomonas infections. They are used in monotherapy or in combination with antimicrobials to treat various infections to overcome drug resistance, particularly in cystic fibrosis patients [4] and infective endocarditis [5]. In the face of systemic infection with septic shock and sepsis, antimicrobial therapy should consist of two antimicrobial agents, with one of these being an aminoglycoside [6], because it exhibits concentrationdependent bactericidal activity and produces prolonged post-antibiotic effects [7].

$\beta$-lactam antibiotic coupled with an aminoglycoside is a commonly used synergistic combination for the treatment of clinical infections. Other combinations include fluoroquinolone and aminoglycosides, and tetracycline and aminoglycosides. Clinical isolates show a high susceptibility to aminoglycosides as compared to other first-line antibiotics [8] Despite high susceptibility to aminoglycosides in clinical isolates, P. aeruginosa exhibits physiological adaptations to these antibiotics, which results in less response to its synergistic combinations.

P. aeruginosa thrives in the inhibitory concentration of antibiotics and acquires adaptive resistance gradually, which makes treatment more complicated [9]. The adaptive resistance mechanism is characterized by the modification of the cytoplasmic membrane, condensation of membrane proteins, and the reduction of phospholipid content [10], which reduces penetration of antibiotics into the plasma membrane. Studies show that adaptive resistance can also develop by the up-regulation of efflux pumps, especially MexXY-OprM [11].

Among immunocompromised patients, P. aeruginosa are favored to adapt to the administered antibiotics and enable better survival of the bacterial generation by emerging as physiologically resistant groups [12]. Adaptive resistance is developed due to rapid transcriptomic alteration in response to antibiotics [13]. A better understanding of the kinetics and transcriptomic changes during antibiotic exposure can develop scientific insight on the adaptive resistance mechanism in P. aeruginosa [13,14]. In light of this, our study was designed to gain a better understanding of the adaptive resistance mechanism in P. aeruginosa to the aminoglycosides gentamicin, amikacin, and tobramycin, which are commonly used as first line antibiotics.

\section{Materials and Methods}

\subsection{Broth Dilution Method}

The minimum inhibitory concentrations (MICs) of P. aeruginosa ATCC 27853 was determined by the broth dilution method as per the Clinical and Laboratory Standards Institute (CLSI) guidelines. MIC assay was performed for gentamicin, amikacin, and tobramycin (purchased from Sigma Aldrich, Bangalore, Karnataka, India) with log phase culture $\left(5 \times 10^{8} \mathrm{CFU} / \mathrm{mL}\right)$ in Mueller Hinton broth (MHB) using a 96-well microtiter plate. The final optical density $\left(\mathrm{OD}_{600}\right)$ at $600 \mathrm{~nm}$ wavelength was determined via an $\mathrm{Epoch}^{\mathrm{TM}}$ Microplate spectrophotometer (BioTek Instruments Inc., Winooski, VT, USA).

\subsection{In Vitro Exposure of Antibiotics to P. aeruginosa}

From the observed MICs in the broth dilution method, antibiotic concentrations of $1 \mu \mathrm{g} / \mathrm{mL}, 2 \mu \mathrm{g} / \mathrm{mL}$, and $3 \mu \mathrm{g} / \mathrm{mL}$ for amikacin and $0.5 \mu \mathrm{g} / \mathrm{mL}, 1 \mu \mathrm{g} / \mathrm{mL}$, and $1.5 \mu \mathrm{g} / \mathrm{mL}$ for gentamicin and tobramycin were prepared separately in $10 \mathrm{~mL}$ of MHB dispensed in Tarsons tubes. P. aeruginosa ATCC 27853 was inoculated and the initial cell density at $\mathrm{OD}_{600}$ was adjusted to $\cong 0.26$ uniformly in all the tubes. The experimental set up was observed for $72 \mathrm{~h}$. The experimental condition was incubated at $37^{\circ} \mathrm{C}$ with optimal shaking at $74 \mathrm{rpm}$. Every $12 \mathrm{~h}$, the turbidity was monitored by measuring the $\mathrm{OD}_{600}$ in an Epoch ${ }^{\mathrm{TM}}$ microtiter plate reader (BioTek Instruments Inc., Winooski, VT, USA) [14,15]. The tubes with growth were sub-cultured in nutrient agar. The colonies were confirmed for P. aeruginosa through the matrix-assisted laser desorption ionization time-of-flight (MALDI-TOF) automated identification system VITEK ${ }^{\circledR}$ MS (BioMérieux, SA, Marcy l'Etoile, France) by following the standard procedure for sample preparation [16]. 


\subsection{In Silico Transcriptomic Analysis}

\subsubsection{Retrieval of Microarray Datasets}

The differential gene expression analysis was performed by exploring microarray datasets from the Gene Expression Omnibus (GEO), NCBI. The datasets which mimicked our experimental condition, P. aeruginosa exposed to an MIC of tobramycin, were available as accessible series no. GSE9991 and GSE9989. Two datasets were analyzed: (1) a tobramycin-treated planktonic culture of P. aeruginosa (GSE9991), and (2) a tobramycintreated P. aeruginosa biofilm (GSE9989). In GSE9991, a planktonic culture of PA14 was exposed to an MIC of tobramycin of $5 \mu \mathrm{g} / \mathrm{mL}$ for $30 \mathrm{~min}$ at $37^{\circ} \mathrm{C}$ [17]. Two samples, GSM252561 and GSM252562, of tobramycin-treated PA14 planktonic culture was taken as a test, which was compared to two controls, GSM252559 and GSM252560, of unexposed PA14 planktonic culture. GSE9989 consisted of six samples, in which three samples (GSM252496, GSM252501, and GSM252505) of unexposed P. aeruginosa biofilm were used as controls, and three samples (GSM252506, GSM252507, and GSM252508) of tobramycin-exposed $P$. aeruginosa biofilm were used as the test. Biofilms were grown on CFBE41o-cells in culture for $9 \mathrm{~h}$ in MEM $/ 0.4 \%$ arginine. Replicate samples were then incubated in the presence or absence of $500 \mu \mathrm{g} / \mathrm{mL}$ tobramycin for $30 \mathrm{~min}$ [17].

In the microarray datasets, before RNA harvesting, cells were washed several times in $2 \mathrm{~mL}$ PBS to remove antibiotics. The RNA was extracted using a RNeasy RNA isolation kit (QIAGEN Inc., Valencia, CA, USA). The bacterial RNA was then purified, using a MICROBEnrich ${ }^{\mathrm{TM}}$ kit (Ambion ${ }^{\circledR}$, Austin, TX, USA), to exclude mammalian RNA. The purified RNA was subjected to cDNA synthesis, followed by microarray preparation according to the Affymetrix GeneChip P. aeruginosa genome array expression analysis protocol [17].

\subsubsection{Differential Gene Expression Analysis}

In the microarray datasets, raw data, available as a platform file, was extracted, formatted, and uploaded as input data in NetworkAnalyst 3.0 (https:/ / www.networkanalyst.ca/, accessed on 28 March 2020). In NetworkAnalyst 3.0, organism ID—P. aeruginosa and data type-intensity table (microarray data) options were selected, and probe summarization was performed by a multi-array average algorithm. The raw data was preprocessed by removing novel genes and hypothetical proteins (unannotated genes). A variance filter score of 15 and low abundance threshold of 5 were applied, and the datasets were normalized by $\log 2$ transformation. Using the linear models for microarray analysis (Limma) statistical package, datasets were subjected to specific comparisons by the test versus control samples to determine the $\log 2$ fold change ( $\mathrm{LogFc}$ ) between the two groups. To identify significant DEGs, the datasets were filtered by a significant threshold cutoff of an adjusted $p$-value of $\leq 0.05$ [18].

\subsubsection{Functional Enrichment Analysis}

DAVID Bioinformatics Resources 6.8 (https:/ / david.ncifcrf.gov/, accessed on 17 April 2020) [19], a computational tool, was used for further downstream analysis of significant DEGs. The databases selected for enrichment analysis in DAVID were the KEGG Pathway, InterPro, GO Terms, UniProtKB, and SMART. A minimum threshold gene count of $\geq 2$ and an EASE Score of 0.1 were set as the cutoff, and only enrichments of $\leq 0.05$ false discovery rate (FDR) were considered for the study. A clustering enrichment analysis was performed by categorizing clustered groups that shared similar functional terms in global annotation profiles across databases. A module-centric approach for DEGs was used to determine similar enrichments for more significance [20]. In the functional annotation clusters, an enrichment score of 2.0 was set as the threshold for the selection of enriched clusters.

DEGs significantly enriched in the functional groups were considered as target genes. Further, target genes were studied functionally using Pseudomonas Genome DB (http:/ / pseudomonas.com/, accessed on 20 April 2020) [21] and PseudoCyc (http: / / www.pseudomonas.com:1555/, accessed on 25 April 2020) [22] to determine the func- 
tion and regulations of DEGs based on previously published resources. The protein-toprotein interactions (PPI) of the regulatory genes were studied using the STRING database (https://string-db.org/, accessed on 2 July 2021) to determine protein and molecular interactions. Only a highly significant interaction score of $\geq 0.850$ was considered for interactions [23,24].

\section{Results}

\subsection{Broth Dilution Method}

The MICs of gentamicin, amikacin, and tobramycin for P. aeruginosa (ATCC 27853) were $0.5 \mu \mathrm{g} / \mathrm{mL}, 1.5 \mu \mathrm{g} / \mathrm{mL}$, and $0.5 \mu \mathrm{g} / \mathrm{mL}$.

\subsection{In Vitro Exposure of Antibiotics to P. aeruginosa}

The initial $\mathrm{OD}_{600}$ of the bacterial culture was $\cong 0.26$ in all the tubes. After $12 \mathrm{~h}$, the cell density dropped to $\cong 0.13$. In the $0.5 \mu \mathrm{g} / \mathrm{mL}$ and $1 \mu \mathrm{g} / \mathrm{mL}$ of gentamicin (Figure 1 ) and $1 \mu \mathrm{g} / \mathrm{mL}$ and $2 \mu \mathrm{g} / \mathrm{mL}$ of amikacin (Figure 2) tubes, the $\mathrm{OD}_{600}$ increased exponentially after $24 \mathrm{~h}$. After $48 \mathrm{~h}$, the bacterial growth attained the initial $\mathrm{OD}_{600}$ of $\cong 0.26$ (Figures 1 and 2 ), and the cells resumed active growth after the post-antibiotic effect. In tobramycin and the higher concentrations of gentamicin and amikacin tubes, after $12 \mathrm{~h}$ the $\mathrm{OD}_{600}$ further declined, and no growth was observed until $72 \mathrm{~h}$ (Figures 1-3). The growth in the tubes of $1 \mu \mathrm{g} / \mathrm{mL}$ and $2 \mu \mathrm{g} / \mathrm{mL}$ of amikacin and the $0.5 \mu \mathrm{g} / \mathrm{mL}$ and $1 \mu \mathrm{g} / \mathrm{mL}$ tubes of gentamicin were confirmed as P. aeruginosa by MALDI-TOF automated identification system, based on peptide mass fingerprint matching.

\section{Gentamicin}

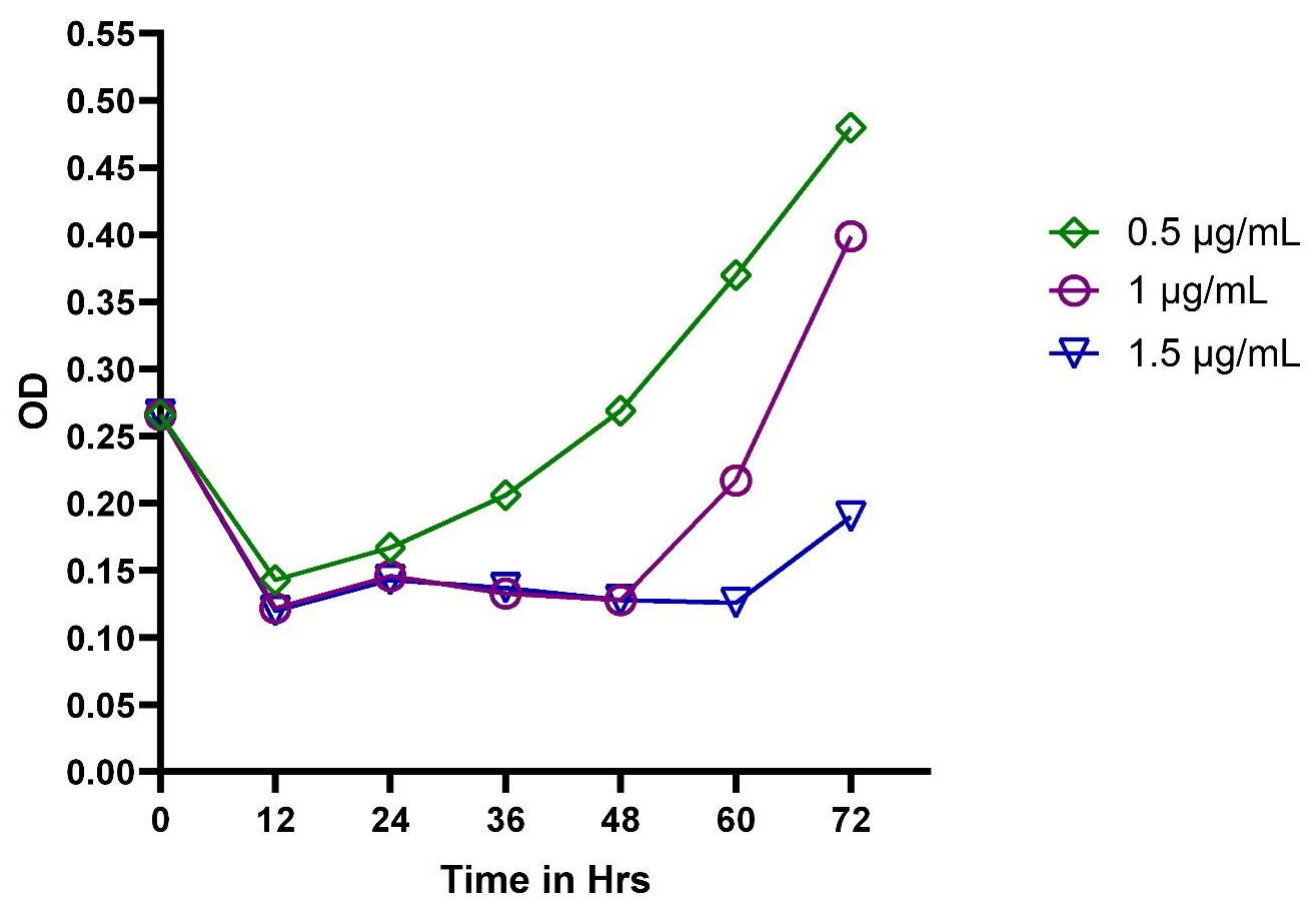

Figure 1. In vitro exposure of MICs $0.5 \mu \mathrm{g} / \mathrm{mL}, 1 \mu \mathrm{g} / \mathrm{mL}$, and $1.5 \mu \mathrm{g} / \mathrm{mL}$ of gentamicin to P. aeruginosa. The $\mathrm{OD}_{600}$ values depict the kinetics of adaptive resistance in the cell. 


\section{Amikacin}

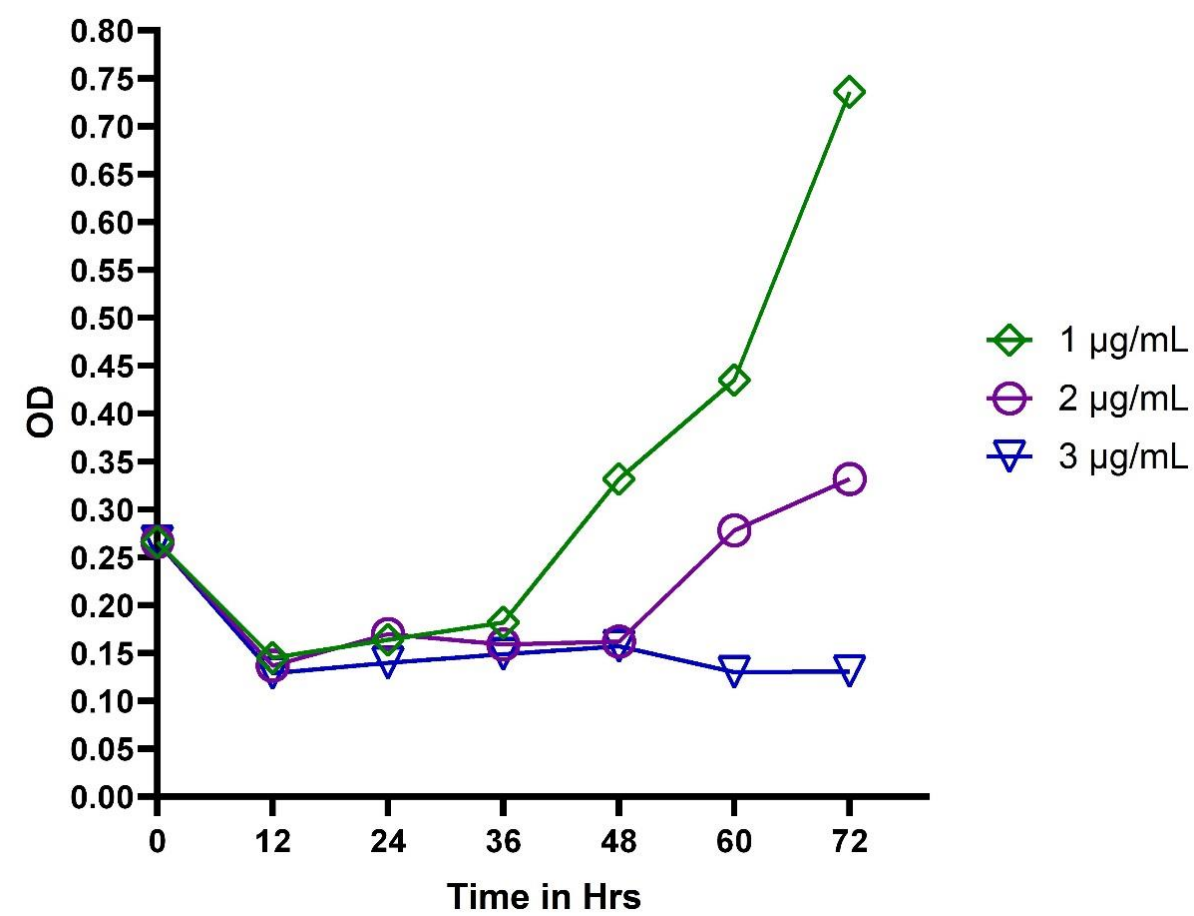

Figure 2. In vitro exposure of MICs $1 \mu \mathrm{g} / \mathrm{mL}, 2 \mu \mathrm{g} / \mathrm{mL}$, and $3 \mu \mathrm{g} / \mathrm{mL}$ of amikacin to P. aeruginosa. The $\mathrm{OD}_{600}$ values depict the kinetics of adaptive resistance in the cell.

Tobramycin

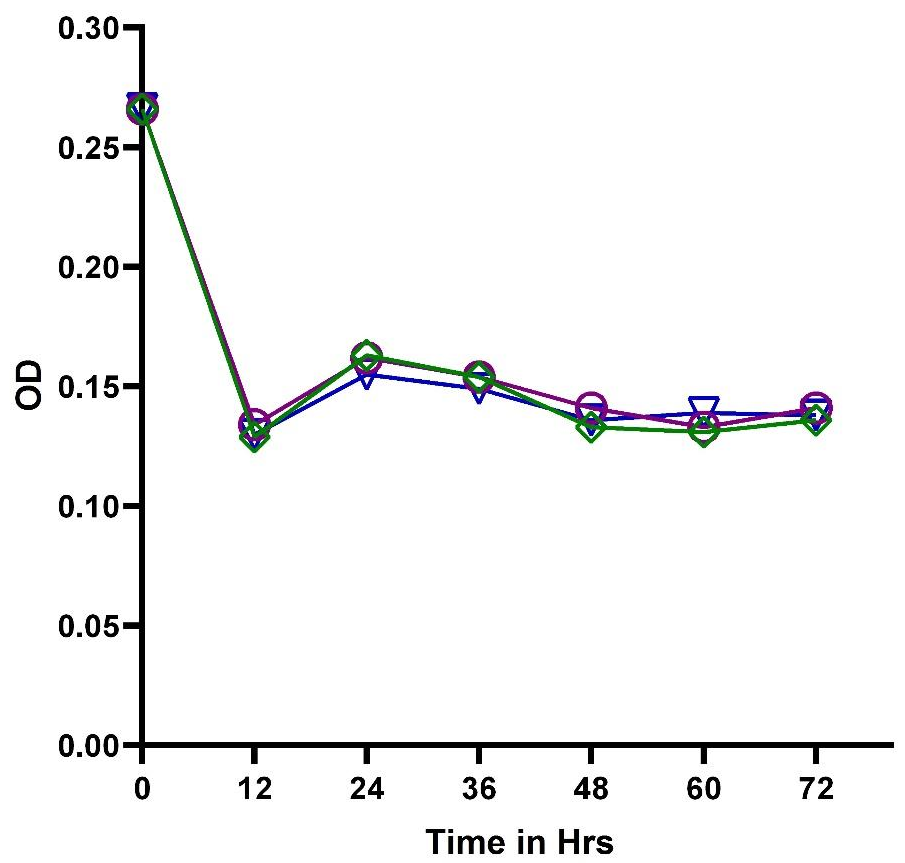

$\vartheta 0.5 \mu \mathrm{g} / \mathrm{mL}$

$\ominus 1 \mu \mathrm{g} / \mathrm{mL}$

$\nabla 1.5 \mu \mathrm{g} / \mathrm{mL}$

Figure 3. In vitro exposure of MICs $0.5 \mu \mathrm{g} / \mathrm{mL}, 1 \mu \mathrm{g} / \mathrm{mL}$, and $1.5 \mu \mathrm{g} / \mathrm{mL}$ of tobramycin to $P$. aeruginosa. The $\mathrm{OD}_{600}$ values depict the kinetics of adaptive resistance in the cell.

\subsection{Differential Gene Expression Analysis}

In GSE9991, 125 genes were differentially expressed. Among them, 53 genes were upregulated and 72 were downregulated. In GSE9989, a total of 307 genes were differentially 
expressed, in which 52 genes were upregulated and 255 genes were downregulated. The distribution of DEGs in both the datasets were represented in a volcano plot (Figure 4). In this study, the targeted DEGs included 17 from GSE9991 and 22 from GSE9989 (Tables 1 and 2).

A

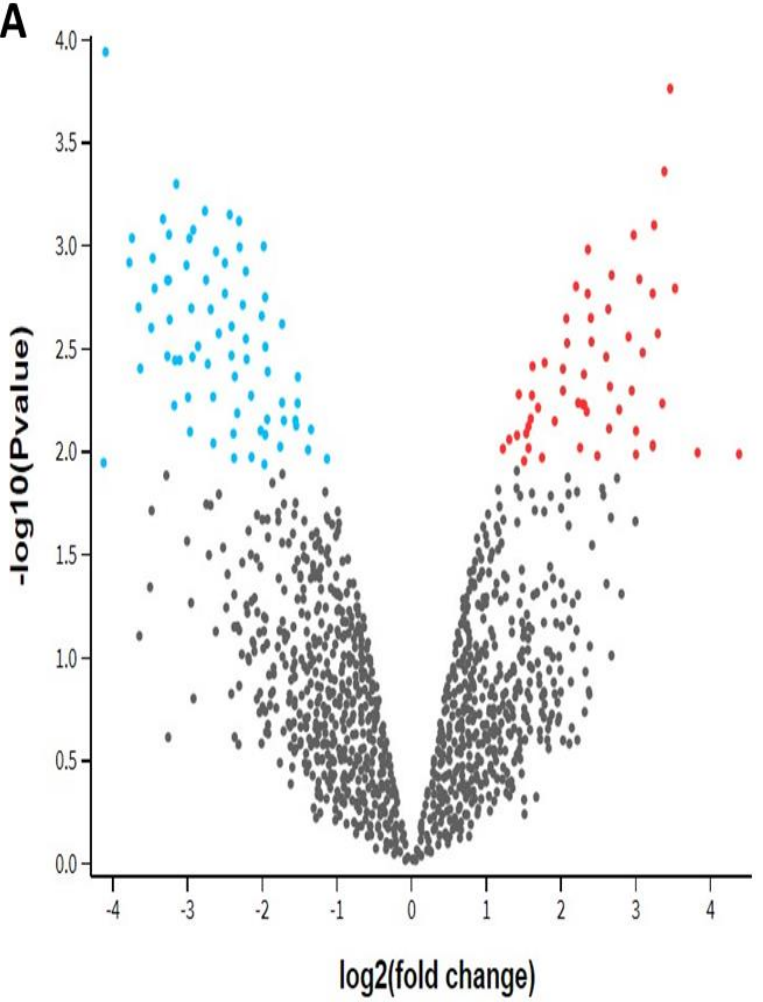

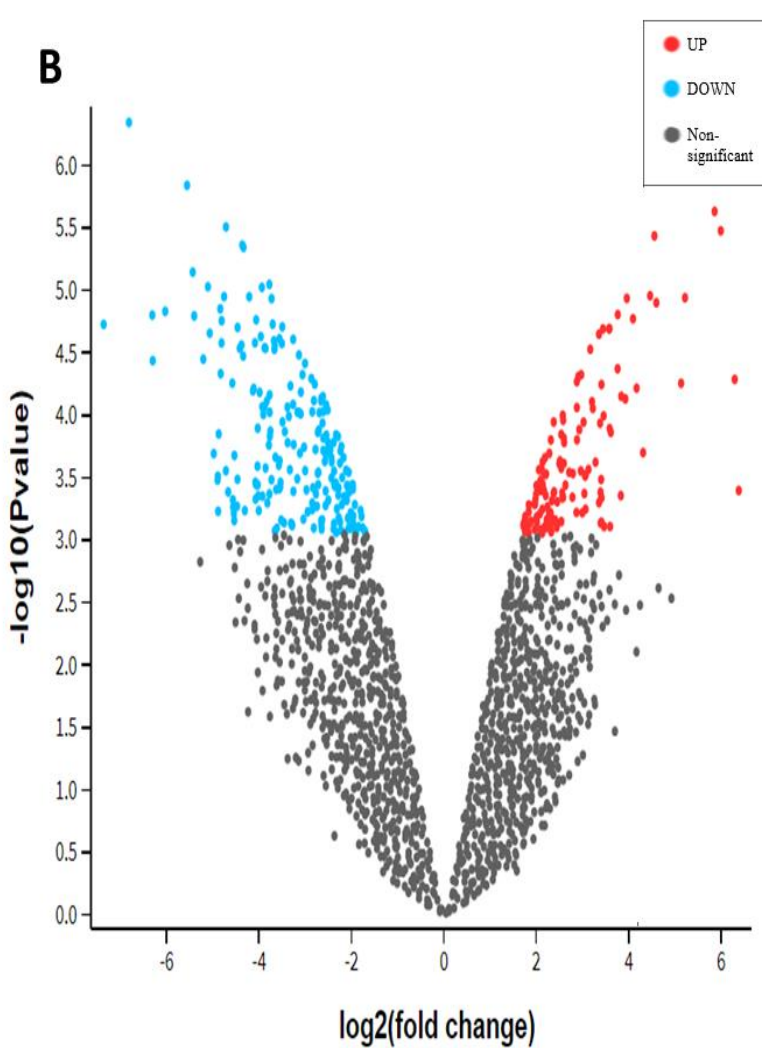

Figure 4. Volcano plots of the microarray datasets representing the distribution of DEGs in tobramycin-treated P. aeruginosa. The (A) volcano plot of GSE9991, tobramycin treated planktonic culture; and (B) volcano plot of GSE9989, tobramycin-treated biofilm. The figure illustrates the degree of variation in the gene expression of P. aeruginosa after exposure to tobramycin.

\subsection{Functional Enrichment Analysis}

The DEGs enriched in the functional classification are presented in Figure 5. The highest enrichment was observed in the bacterial secretory system from the KEGG pathways (Figure 6). All the DEGs enriched in this pathway were downregulated in the type III and type II toxin system.

DEGs enriched in similar functional groups across databases were clustered as functional annotation clusters with a significant enrichment score (Table 3). The enriched clusters shared similar functional terms in type II and type III toxin secretion system (cluster 1), methylation (cluster 2), and RNA methyltransferase and rRNA processing (cluster 3). 
Table 1. List of target DEGs and log fold change of expression in tobramycin-treated planktonic $P$. aeruginosa (GSE9991).

\begin{tabular}{ccc}
\hline Genes & Log Fc & Adj. $p$-Value \\
\hline$P A 2677$ & -2.21809 & 0.0013 \\
$P A 0687$ & -1.44816 & 0.0287 \\
$P A 2672$ & -1.23836 & 0.0271 \\
$x c p R$ & -0.28436 & 0.0332 \\
$x c p U$ & -0.50274 & 0.0200 \\
$x c p V$ & -0.19849 & 0.0484 \\
$x c p Y$ & -0.22214 & 0.0436 \\
$x c p Z$ & -0.21626 & 0.0496 \\
$t a d B$ & -0.16973 & 0.0407 \\
tadD & -0.25359 & 0.0387 \\
algR & -0.35921 & 0.0284 \\
algL & 0.640009 & 0.0280 \\
pslF & -1.03452 & 0.0478 \\
PA1839 & 2.200892 & 0.0015 \\
PA0419 & -0.92439 & 0.0339 \\
$P A 0017$ & -0.33728 & 0.0257 \\
$P A 3680$ & -0.34165 & 0.0065 \\
\hline
\end{tabular}

Table 2. List of target DEGs and log fold change of expression in tobramycin-treated P. aeruginosa biofilm (GSE9989).

\begin{tabular}{lcc}
\hline Genes & Log Fc & Adj. $\boldsymbol{p}$-Value \\
\hline$m u c A$ & 4.094536 & 0.0035 \\
$m u c B$ & 1.155318 & 0.0062 \\
$l e x A$ & 3.42962 & 0.0035 \\
$g i d B$ & -3.31909 & 0.0050 \\
$p s c Q$ & -2.35821 & 0.0105 \\
$p s c P$ & -3.64432 & 0.0155 \\
$p s c R$ & -3.11905 & 0.0346 \\
$p s c G$ & -1.75324 & 0.0061 \\
$p s c H$ & -1.52118 & 0.0381 \\
$p s c E$ & -3.84799 & 0.0501 \\
$p s c F$ & -1.3676 & 0.0122 \\
$p s c I$ & -2.27261 & 0.0176 \\
$p s c J$ & -1.43567 & 0.0491 \\
$p s c K$ & -1.6767 & 0.0129 \\
$x c p Q$ & -2.31778 & 0.0307 \\
$x c p S$ & -1.40397 & 0.0273 \\
$x c p T$ & -0.72049 & 0.0273 \\
$x c p U$ & -1.33575 & 0.0248 \\
$x c p V$ & -3.11543 & 0.0281 \\
$x c p W$ & -0.69783 & 0.0323 \\
$x c p X$ & -0.42221 & 0.0530 \\
$x c p Y$ & -0.5616 & 0.0380 \\
\hline
\end{tabular}




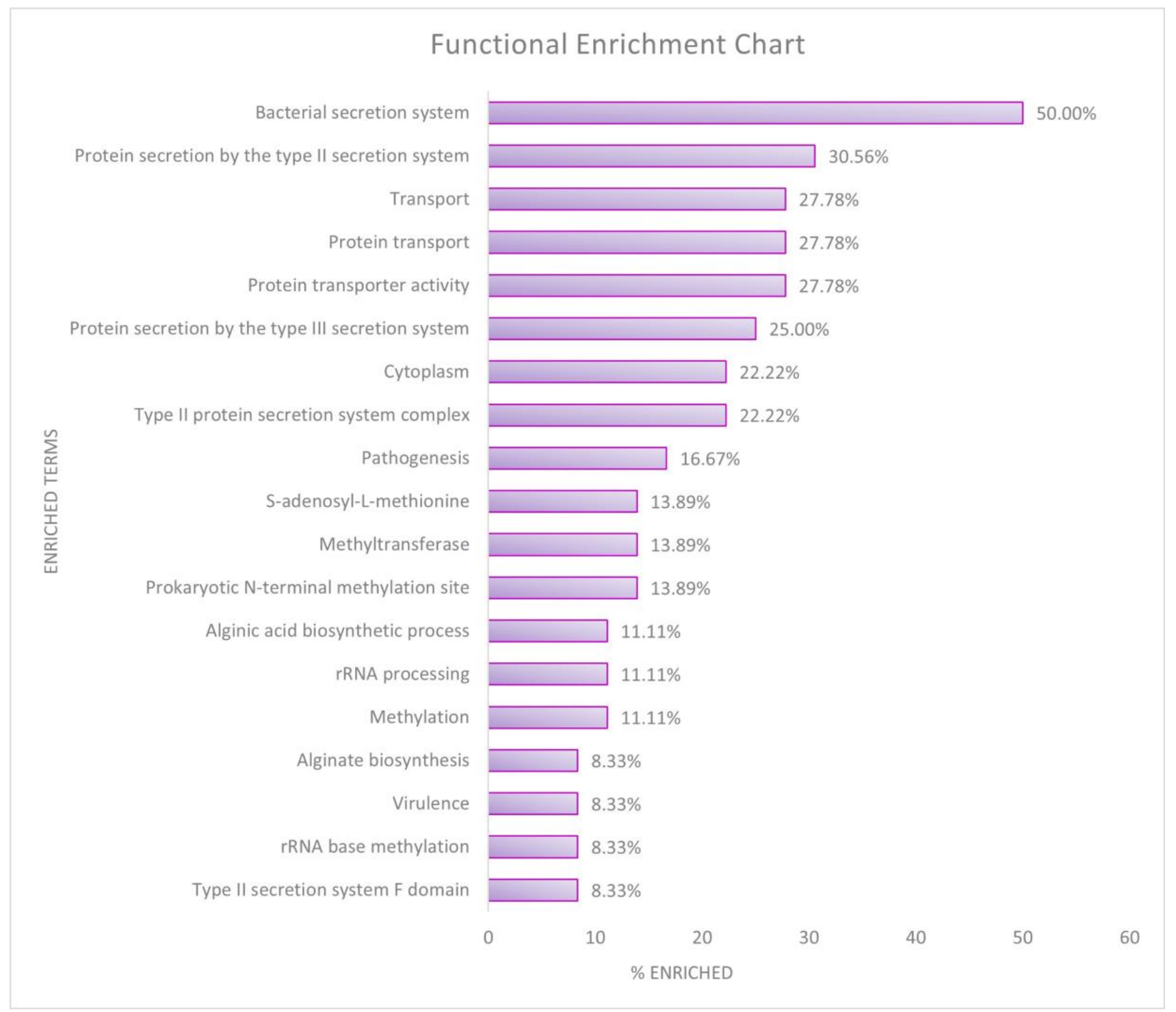

Figure 5. Functional enrichments of DEGs. The functional classification of DEGs were performed in the DAVID Bioinformatics Resources 6.8 and the enrichments of various pathways and terms are represented in this graph. 
BACTERIAL SECRETION SYSTEM

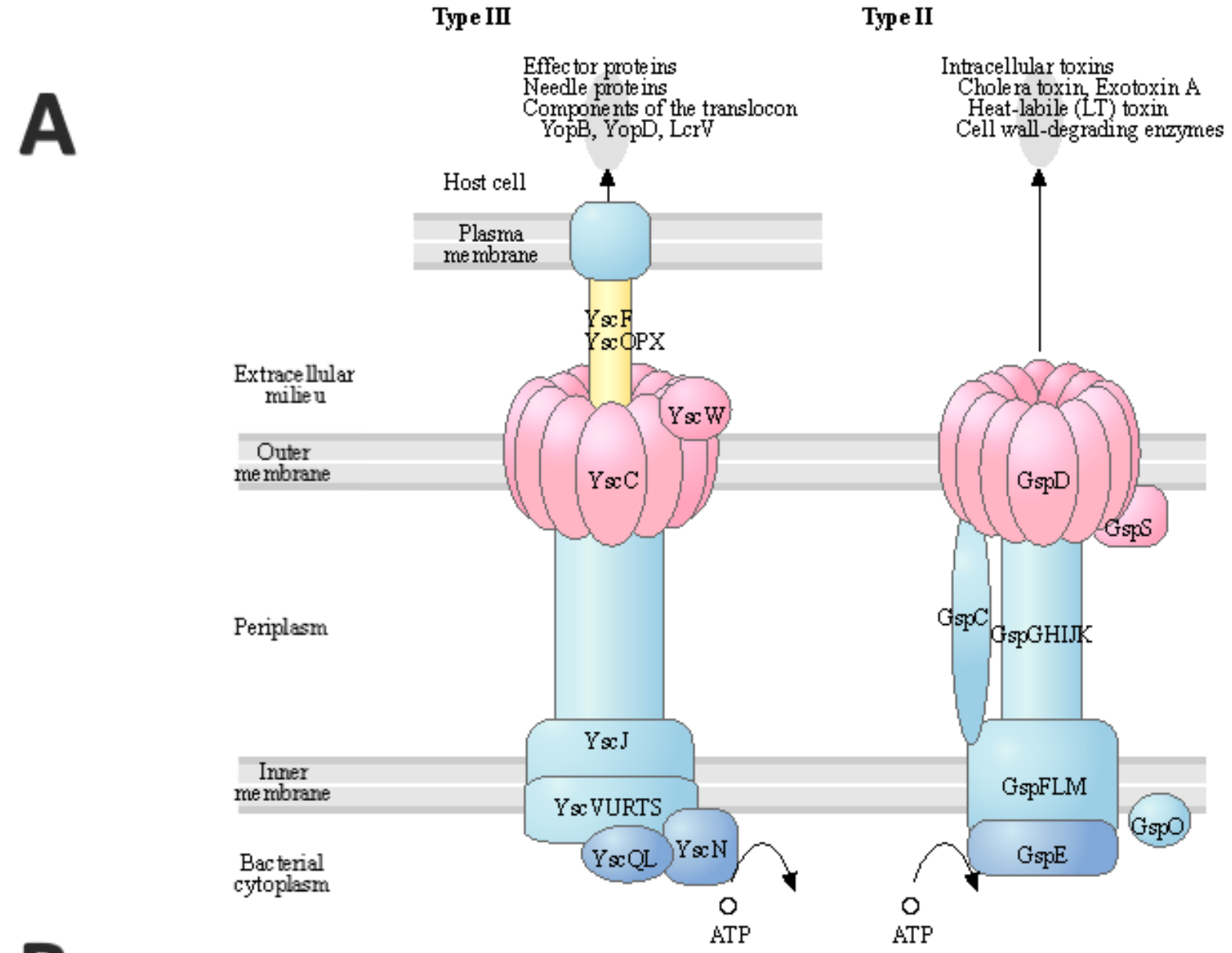

\section{Type III}

\begin{tabular}{|c|c|c|c|}
\hline \multirow[t]{2}{*}{ Needle } & $Y s F$ & & \\
\hline & $\mathrm{YsO}$ & $Y s P$ & $Y s X$ \\
\hline \multirow{2}{*}{$\begin{array}{r}\text { Secretin } \\
\text { OMP }\end{array}$} & $\mathrm{YsC}$ & & \\
\hline & $Y s W$ & & \\
\hline \multirow{2}{*}{$\begin{array}{l}\text { Inner membrane protein } \\
\text { (IMP) }\end{array}$} & $Y \approx J$ & $Y s R$ & $Y x S$ \\
\hline & $\mathrm{Y} \propto \mathrm{T}$ & $\mathrm{Y} s \mathrm{U}$ & $\mathrm{Y} \times \mathrm{V}$ \\
\hline ATPase & $\mathrm{YsN}$ & & \\
\hline $\begin{array}{l}\text { ATPase-associated } \\
\text { protein }\end{array}$ & $Y s Q$ & $Y \propto L$ & \\
\hline
\end{tabular}

\section{Type II}

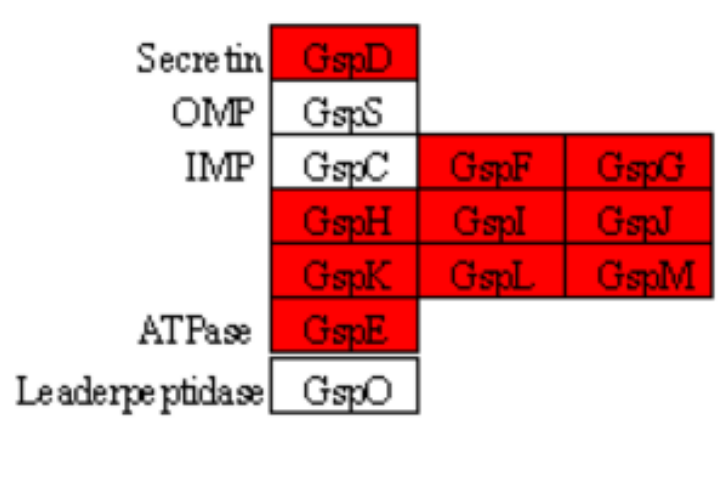

Figure 6. The architecture of type III and type II bacterial secretory system. The (A) distribution of various protein domains in type III and type II toxin exports, and (B) the set of proteins in the type III and type II system. The red highlight denotes the proteins coded by the downregulated genes that are enriched in bacterial secretory system from KEGG pathways. Type III export proteins YscF ( $p s c F)$, YscJ $(p s c)$ ), translocation protein YscR ( $p s c R), Y s c Q(p s c Q)$, and YscP ( $p s c P)$ were downregulated in T3SS. Type II secretion proteins GspD ( $x c p Q)$, GspE ( $x c p R), \mathrm{GspF}(x c p S)$, GspG (xcpT), GspH ( $x c p U)$, GspI $(x c p V), \mathrm{GspJ}(x c p W), \mathrm{GspK}(x c p X), \mathrm{GspL}(x c p Y)$, and GspM (xcpZ) were downregulated in T2SS. 
Table 3. Clustering enrichment analysis of the DEGs from various databases. The clusters grouped with significant enrichment scores are listed. Performed in the source DAVID Bioinformatics Resources 6.8.

\begin{tabular}{|c|c|c|c|c|}
\hline Databases & Clusters & $\%$ Enriched & Fold Enrichment & FDR \\
\hline & $\begin{array}{c}\text { Cluster 1-Type II and Type III toxin } \\
\text { secretion system }\end{array}$ & & & \\
\hline KEGG Pathways & Bacterial secretion system & 50.00 & 16.68 & $2.93 \times 10^{-20}$ \\
\hline GO Term-Biological Process & Protein secretion by type II secretion system & 30.56 & 43.27 & $8.77 \times 10^{-14}$ \\
\hline GO Term-Molecular Functions & Protein transporter activity & 27.78 & 52.90 & $2.65 \times 10^{-13}$ \\
\hline UniProtKB & Protein transport & 27.78 & 33.91 & $1.89 \times 10^{-10}$ \\
\hline GO Term-Cellular component & Type II protein secretion system complex & 22.22 & 42.90 & $1.33 \times 10^{-9}$ \\
\hline \multirow[t]{2}{*}{ UniProtKB } & Transport & 27.78 & 4.31 & 0.003997 \\
\hline & & \multicolumn{3}{|c|}{ Cluster 1 Enrichment Score: 12.16} \\
\hline & Cluster 2-Methylation metabolism & & & \\
\hline GO Term-Cellular component & Type II protein secretion system complex & 22.22 & 42.90 & $1.33 \times 10^{-9}$ \\
\hline InterPro & Prokaryotic N-terminal methylation site & 13.89 & 38.23 & $4.58 \times 10^{-4}$ \\
\hline \multirow[t]{3}{*}{ UniProtKB } & Methylation & 11.11 & 35.91 & 0.003334 \\
\hline & & \multicolumn{3}{|c|}{ Cluster 2 Enrichment Score: 6.32} \\
\hline & $\begin{array}{c}\text { Cluster } 3 \text { - RNA methyltransferase and } \\
\text { rRNA processing }\end{array}$ & & & \\
\hline UniProtKB & Methyltransferase & 13.89 & 11.56 & 0.007267 \\
\hline UniProtKB & rRNA processing & 11.11 & 19.69 & 0.007267 \\
\hline UniProtKB & S-adenosyl-L-methionine & 13.89 & 10.75 & 0.007267 \\
\hline GO Term-Biological Process & rRNA base methylation & 8.33 & 36.88 & 0.010077 \\
\hline \multirow[t]{2}{*}{ UniProtKB } & Cytoplasm & 22.22 & 3.16 & 0.047188 \\
\hline & & \multicolumn{3}{|c|}{ Cluster 3 Enrichment Score: 2.06} \\
\hline
\end{tabular}

From Pseudomonas Genome DB and PseudoCyc, we found that the targeted DEGs regulated the functions of RNA methyltransferases, $16 \mathrm{~S}$ rRNA 7-methylguanosine methyltransferase, repressors for alginate synthesis, type II secretary proteins, type II transport domains, translocation protein in type III secretion, and type III export protein.

The PPI of gidB coding for methyltransferase activity (Figure 7) and mucA coding for repressor of alginate synthesis (Figure 8) were constructed using the STRING interaction network. 


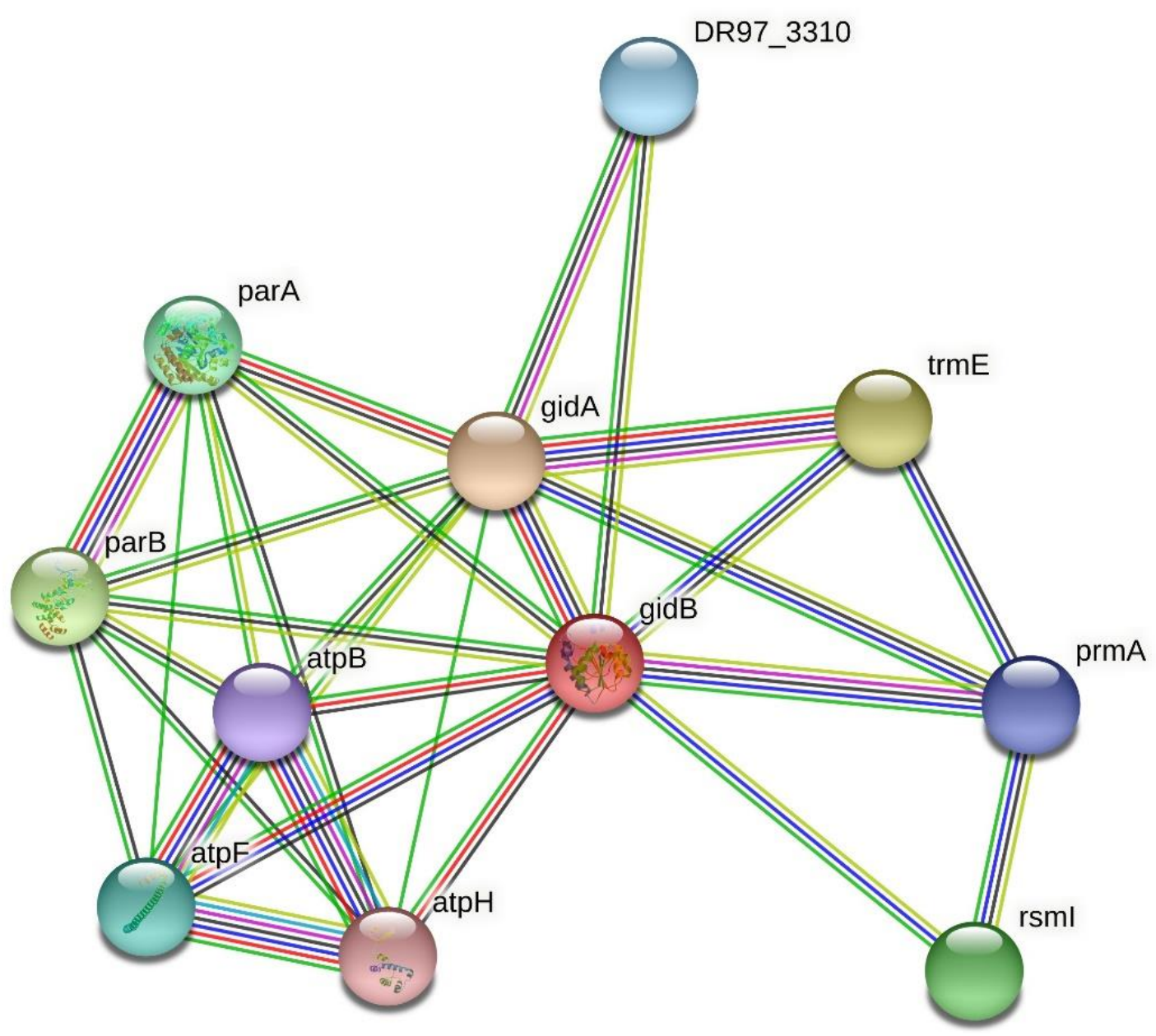

\section{Node Color}

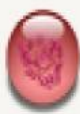

colored nodes:

query proteins and first shell of interactors

white nodes:

second shell of interactors

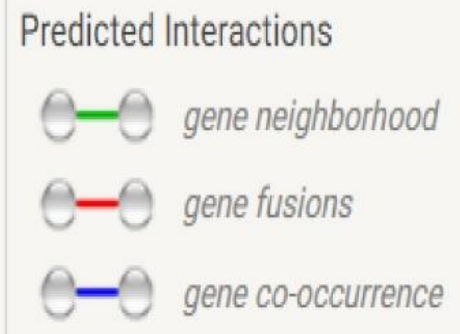

Known Interactions

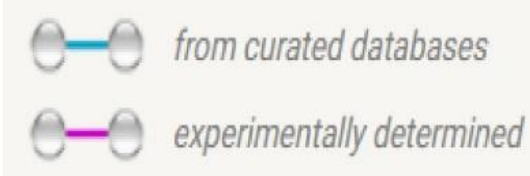

\section{Node Content}

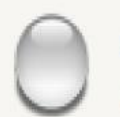

empty nodes:

proteins of unknown 30 structure

\section{filled nodes:}

some $3 D$ structure is known or predicted

\section{Others}

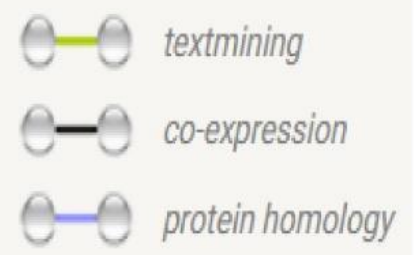

Figure 7. PPI network of gidB. The network shows the significant STRING interactions of gidB with its gene neighbors. The predicted functional partners of $\operatorname{gid} B$ were $\operatorname{gid} A, \operatorname{trm} E$, parB, $\operatorname{rsmL} \operatorname{par} A$, atpF, $\operatorname{prm} A$, atpB, and atpH in RNA methylation metabolism. 


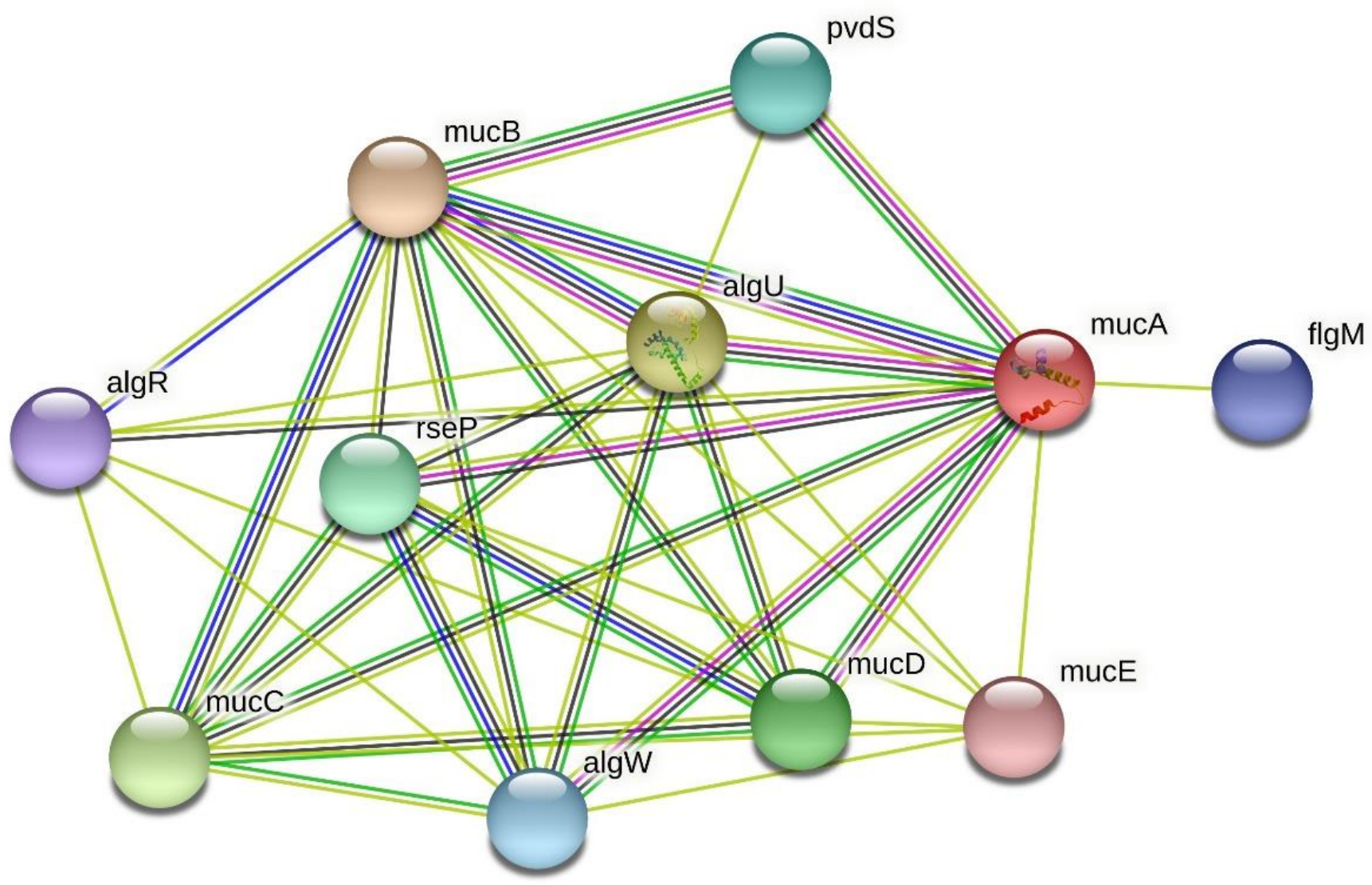

Node Color

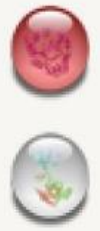

colored nodes:

query proteins and first shell of interactors

white nodes:

second shell of interactors

\section{Known Interactions}

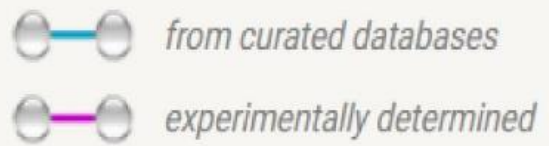

\section{Node Content}

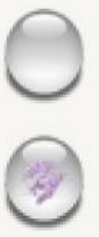

empty nodes:

proteins of unknown 30 structure

\section{filled nodes:}

some $3 D$ structure is known or predicted

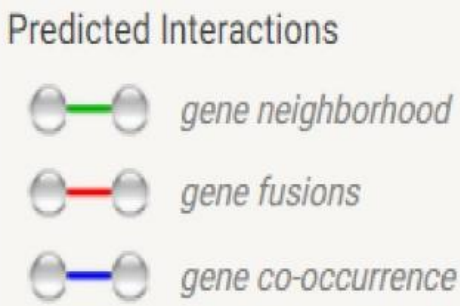

\section{Others}

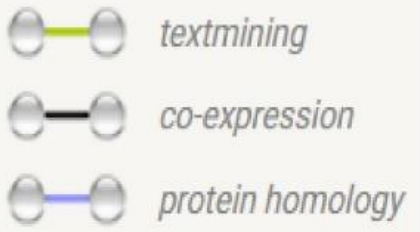

Figure 8. PPI network of $m u c A$. The network shows the significant STRING interactions of $m u c A$ with its gene neighbors. The predicted functional partners of $m u c A$ were $m u c B, \operatorname{alg} U, m u c C, m u c D, r s e P, p v d S, \operatorname{alg} W, f \lg M$, algR, and $m u c E$ in alginate biosynthesis metabolism.

\section{Discussion}

The bacterial populations in the MICs experience antibiotic stress, which triggers the tolerance mechanism by regulating transcriptional changes in P. aeruginosa. The experimental setup of the in vitro treatment of antibiotics to $P$. aeruginosa reflects the antibiotic tolerance in chronic infections, where the response to antimicrobials is reduced due to the development of adaptive resistance [25]. Among the antibiotics evaluated for tolerance 
in $P$. aeruginosa, tobramycin exhibited a superior post-antibiotic effect in all the MICs and was found to be more effective at suppressing the bacterial sub-populations. Further, in silico analysis of the DEGs in the microarray datasets mimicking our experimental condition exposed the possible effectiveness of tobramycin in antibiotic tolerance. Anderson et al. published the microarray datasets of $P$. aeruginosa exposed to MIC of tobramycin in 2008 [17]. We further performed functional enrichment analysis for the DEGs and its putative gene regulations.

In the microarray datasets, the functional enrichment analysis enabled preliminary classification of the DEGs. The functional enrichments of the DEGs were observed in RNA methylation metabolism, alginate biosynthesis, and type II and type III secretory systems, which accounts for the resistance and virulence in $P$. aeruginosa. Anderson et al. reported the downregulation of drug efflux transporter genes PA1541, mexB and mexR, which contributed to efflux pump mediated resistance [26]. We further explored the methylation genes coding resistance to aminoglycosides by target methylation. Methylation of 16s rRNA by methyltransferase is a common mechanism of resistance to aminoglycosides, leading to a loss of affinity of the drug to the target [27]. RNA methyltransferases: PA0419, a ribosomal RNA small subunit methyltransferase E, which methylates 16s rRNA bases in 30s subunit, was downregulated. PA0017 and PA3680 genes of class B and J methyltransferase also lagged in expression. 16S rRNA 7-methylguanosine methyltransferase: gidB belongs to methyltransferase $\mathrm{G}$, which involves methylation of the seventh nucleotide guanosine, confers resistance to aminoglycoside by decreasing the binding affinity to its target [28]. The PPI of gidB was determined to study its functionally associated genes of RNA modifying enzymes in the gid operon (Figure 7). Among the interactions, gidA, trmE, parB, rsmL, and par $A$ genes exhibited the most significant association and they participated in the RNA methylation metabolism [29]. Hence, gidB may serve as a hub gene for 16S rRNA methylation in P. aeruginosa. A low expression of gidB ( $\log \mathrm{Fc}-3.32)$ and the gene expression profile of methyltransferases suggested a low incidence of resistance development during tobramycin exposure. The following observations also extend the insights in adaptive resistance mechanism and the possibility of regulation control of RNA methyltransferases by $P$. aeruginosa during antibiotic exposure.

In chronic infections caused by $P$. aeruginosa, biofilm formation is common during the course of infection [30], conferring additional resistance from host defenses and antibiotics [31]. Some antibiotics are involved in the up-regulation of genes that are responsible for induction of alginate production, which results in reduced antigen presentation to the immune system [32]. In addition, biofilms of $P$. aeruginosa also contribute to antibiotic tolerance, and the regulation of several biofilm-forming genes will affect the persistence of the cells in antibiotics [33]. Alginate Biosynthesis: $\operatorname{alg} L$, a lyase precursor that participates in catabolic activity of alginic acid, which leads to deconstruction of alginate complex [34], was highly expressed. Regulatory protein of alginate biosynthesis genes, algR [35], declined in expression. The gene $p s l F$, which was low expressed ( $\mathrm{LogFc}-1.03)$, is part of the glycosyltransferase family and is involved in the extracellular polysaccharide biosynthetic pathway [36]. Repressors for alginate synthesis: algU is the sigma factor for alginate biosynthesis genes. The gene mucA codes for anti-sigma factor and negatively regulates $\operatorname{alg} U$ [37]. The gene $m u c B$ also regulates the alg $U$ activity in a negative manner, along with $m u c A$. The high expression of $m u c A(\operatorname{LogFc} 4.09)$ and $m u c B(\operatorname{LogF} c 1.15)$ may downregulate the alginate biosynthesis. Anderson et al. reported a set of alginate biosynthesis genes that were differentially expressed. We further predicted the regulations of $m u c A$ and their PPI between gene neighbors to determine the functional partners (Figure 8). The negative transcriptional regulator, $m u c A$, shared significant gene interacting neighbors with $m u c B$, $\operatorname{alg} U, m u c C, m u c D, r s e P, \operatorname{alg} W, \operatorname{alg} R$, and $m u c E$. These genes were reported in the regulations of mucoid conversion of $P$. aeruginosa, responsible for the alginate production. Hence, $m u c A$ and alg $U$ are the determining factors for alginate regulation [37]. The following transcriptional changes, observed in $m u c A, m u c B$, algR, algL, and $p s l F$, would possibly affect the alginate production to a significant level in the presence of tobramycin treatment. 
Previous studies suggested that the toxin-anti-toxin system mediates persister cells in antibiotics. Although studies in E. coli showed evidence for the mechanism [38], it was not clear in P. aeruginosa. The DEGs in the type II and type III secretary system were enriched in the bacterial secretion system of KEGG pathways, and the downregulated genes in the system, coding for various protein domains in the type II and type III secretary system, are represented in Figure 6. Anderson et al. reported the marked downregulation of three transcripts, pscE, pscI, and PA1692, in the type III secretary system. We further explored the panel of genes that prime the interactions in both the type III secretary system and the type II secretary system. Type II Secretary Proteins: PA2677, PA2672, and $P A 0687$, which engage in catalytic and transporter protein activity, were downregulated. Other transporter domains, namely $x c p R, x c p U, x c p V, x c p X, x c p Y, x c p Z, t a d B$, and tadD, were also low expressed [39], affecting the T2SS. Type II Transport Domains: $x c p Q, x c p S$, $x c p T, x c p U, x c p V, x c p W, x c p X$, and $x c p Y$, which involve the efflux of the toxin from a cytosolic domain $x c p R$, were down-regulated and thus affected the export of T2SS [40]. Translocation protein in type III secretion: $p s c Q, p s c P$, and $p s c R$ are translocation proteins of the type III secretion system, which translocate the toxin across the host cell cytoplasmic membrane [41]. Downregulation of $p s c Q$ negatively impacted the toxin delivery to the cytosol of the host cell. Type III Export protein: $p s c E, p s c F, p s c G, p s c H, p s c I$, pscJ, and $p s c K$ are the export proteins of the type III secretion system present in the cytoplasmic membrane, which transfer the toxin from the cytosolic domain to the MS ring of basal body [40]. Low expression of all these proteins prevent toxins from reaching the filament where it is translocated into the host cell. The following transcriptomic changes suggest the suppression of T2SS and T3SS, which may reduce the virulence of the P. aeruginosa during tobramycin treatment.

Anderson et al. observed similar changes in the reduction of the virulence and biofilm formation in $P$. aeruginosa after tobramycin treatment. Our study targeted a different panel of DEGs involved in the aminoglycoside resistance, biofilm formation and virulence mechanism, which are suitable to elucidate the antibiotic tolerance mechanism during antibiotic treatment. Our observations suggest that tobramycin treatment possibly reduces the regulations of RNA methyltransferases, alginate biosynthesis, and T2SS and T3SS in P. aeruginosa.

Spontaneous exposure of antibiotics in the bacterial population alters transcriptional regulation, favoring adaptive resistance which out-turns the fall in antibiotic activity over time [42]. This study suggested the use of tobramycin for treatment of chronic pseudomonas infection, as $P$. aeruginosa failed to develop adaptive resistance to tobramycin and exhibited a positive transcriptomic regulation for antibiotic response. Tobramycin is restricted for systemic use due to the rise of creatinine level during the initial days of therapy. Considering the in vivo drug response, tobramycin might enable a better treatment alternative as compared to current drug combinations.

Transcriptional alterations in microbes are dynamic events triggered by environmental changes, which out-turns the increase in adaptive resistance. Although adaptive resistance is involved in the increase of baseline MICs of the bacteria over time, genetic resistance is a function of time. It takes several generations of the bacteria to achieve genotypic resistance. The methodology of constantly switching antibiotics through in vitro exposure of antibiotics would enable us to decipher which clinical isolates would be physiologically resistant, leading to alternative aminoglycoside treatment for combating chronic infections.

Author Contributions: Conceptualization, A.K.B., B.T. and A.G.; Formal analysis, B.T. and A.G.; Investigation, A.K.B.; Methodology, A.K.B. and B.T.; Project administration, A.K.B. and A.J.; Resources, A.J.; Supervision, B.T.; Visualization, A.J.; Writing—original draft, A.K.B.; Writing—review \& editing, B.T., A.J. and A.G. All authors have read and agreed to the published version of the manuscript.

Funding: This research received no external funding.

Institutional Review Board Statement: Not applicable.

Informed Consent Statement: Not applicable. 
Data Availability Statement: All data are available within the manuscript with relevant citations.

Acknowledgments: We would like to express our gratitude to the Department of Microbial Biotechnology, Bharathiar University for laboratory access and technical support. We are thankful to Angayarkanni Jayaraman for guidance during the study period.

Conflicts of Interest: The authors declare that there is no conflict of interest.

\section{References}

1. Carmeli, Y.; Troillet, N.; Eliopoulos, G.M.; Samore, M.H. Emergence of antibiotic-resistant Pseudomonas aeruginosa: Comparison of risks associated with different antipseudomonal agents. Antimicrob. Agents Chemother. 1999, 43, 1379-1382. [CrossRef]

2. Zhanel, G.G.; Clark, N.; Lynch, J.P. Emergence of antimicrobial resistance among Pseudomonas aeruginosa: Implications for therapy. Semin. Respir. Crit. Care Med. 2017, 38, 326-345. [CrossRef]

3. Bassetti, M.; Vena, A.; Croxatto, A.; Righi, E.; Guery, B. How to manage Pseudomonas aeruginosa infections. Drugs Context 2018, 7, 212527. [CrossRef]

4. Prayle, A.; Smyth, A. Aminoglycoside use in cystic fibrosis: Therapeutic strategies and toxicity. Curr. Opin. Pulm. Med. 2010, 16, 604-610. [CrossRef]

5. Falagas, M.E.; Matthaiou, D.; Bliziotis, I.A. The role of aminoglycosides in combination with a $\beta$-lactam for the treatment of bacterial endocarditis: A meta-analysis of comparative trials. J. Antimicrob. Chemother. 2006, 57, 639-647. [CrossRef]

6. Bodmann, K. Current guidelines for the treatment of severe pneumonia and sepsis. Chemotherapy 2005, 51, 227-233. [CrossRef]

7. Dornbusch, K.; Olofsson, C.; Holm, S. Postantibiotic effect and postantibiotic sub-mic effect of dirithromycin and erythromycin against respiratory tract pathogenic bacteria. APMIS 1999, 107, 505-513. [CrossRef] [PubMed]

8. Patel, J.A.; Javiya, V.A.; Ghatak, S.B.; Patel, K.R. Antibiotic susceptibility patterns of Pseudomonas aeruginosa at a tertiary care hospital in Gujarat, India. Indian J. Pharmacol. 2008, 40, 230-234. [CrossRef] [PubMed]

9. Karlowsky, J.A.; Saunders, M.H.; Harding, G.A.; Hoban, D.J.; Zhanel, G.G. In Vitro characterization of aminoglycoside adaptive resistance in Pseudomonas aeruginosa. Antimicrob. Agents Chemother. 1996, 40, 1387-1393. [CrossRef] [PubMed]

10. Gilleland, L.B.; Gilleland, H.E.; Gibson, J.A.; Champlin, F.R. Adaptive resistance to aminoglycoside antibiotics in Pseudomonas aeruginosa. J. Med. Microbiol. 1989, 29, 41-50. [CrossRef]

11. Hocquet, D.; Vogne, C.; El Garch, F.; Vejux, A.; Gotoh, N.; Lee, A.; Lomovskaya, O.; Plésiat, P. MexXY-OprM efflux pump is necessary for adaptive resistance of Pseudomonas aeruginosa to aminoglycosides. Antimicrob. Agents Chemother. 2003, 47, 1371-1375. [CrossRef]

12. Moradali, M.F.; Ghods, S.; Rehm, B.H.A. Pseudomonas aeruginosa lifestyle: A paradigm for adaptation, survival, and persistence. Front. Cell. Infect. Microbiol. 2017, 7, 39. [CrossRef]

13. Esani, S.; Chen, T.; Leung, K.P.; Van Laar, T.A. Transcriptome sequence of antibiotic-treated Pseudomonas aeruginosa. Microbiol. Resour. Announc. 2019, 8, e01367-18. [CrossRef] [PubMed]

14. Lonergan, Z.; Nairn, B.L.; Wang, J.; Hsu, Y.-P.; Hesse, L.; Beavers, W.N.; Chazin, W.J.; Trinidad, J.C.; VanNieuwenhze, M.S.; Giedroc, D.P.; et al. An Acinetobacter baumannii, zinc-regulated peptidase maintains cell wall integrity during immune-mediated nutrient sequestration. Cell Rep. 2019, 26, 2009-2018.e6. [CrossRef]

15. Berti, A.D.; Wergin, J.E.; Girdaukas, G.G.; Hetzel, S.J.; Sakoulas, G.; Rose, W.E. Altering the proclivity towards daptomycin resistance in methicillin-resistant staphylococcus aureus using combinations with other antibiotics. Antimicrob. Agents Chemother. 2012, 56, 5046-5053. [CrossRef]

16. Mellmann, A.; Cloud, J.; Maier, T.; Keckevoet, U.; Ramminger, I.; Iwen, P.; Dunn, J.; Hall, G.; Wilson, D.; LaSala, P.; et al. Evaluation of matrix-assisted laser desorption ionization-time-of-flight mass spectrometry in comparison to 16S rRNA gene sequencing for species identification of Nonfermenting bacteria. J. Clin. Microbiol. 2008, 46, 1946-1954. [CrossRef] [PubMed]

17. Anderson, G.G.; Moreau-Marquis, S.; Stanton, B.A.; O'Toole, G.A. In Vitro analysis of tobramycin-treated Pseudomonas aeruginosa biofilms on cystic fibrosis-derived airway epithelial cells. Infect. Immun. 2008, 76, 1423-1433. [CrossRef]

18. Xia, J.; Gill, E.E.; Hancock, R. NetworkAnalyst for statistical, visual and network-based meta-analysis of gene expression data. Nat. Protoc. 2015, 10, 823-844. [CrossRef] [PubMed]

19. Huang, D.W.; Sherman, B.T.; Lempicki, R.A. Bioinformatics enrichment tools: Paths toward the comprehensive functional analysis of large gene lists. Nucleic Acids Res. 2009, 37, e16. [CrossRef] [PubMed]

20. Freudenberg, J.; Joshi, V.K.; Hu, Z.; Medvedovic, M. Clean: Clustering enrichment analysis. BMC Bioinform. 2009, 10, 234. [CrossRef] [PubMed]

21. Winsor, G.L.; Griffiths, E.J.; Lo, R.; Dhillon, B.K.; Shay, J.A.; Brinkman, F.S.L. Enhanced annotations and features for comparing thousands of Pseudomonas genomes in the Pseudomonas genome database. Nucleic Acids Res. 2016, 44, D646-D653. [CrossRef] [PubMed]

22. Romero, P.; Karp, P. PseudoCyc, a pathway-genome database for Pseudomonas aeruginosa. J. Mol. Microbiol. Biotechnol. 2003, 5 , 230-239. [CrossRef] [PubMed]

23. Snel, B. String: A web-server to retrieve and display the repeatedly occurring neighbourhood of a gene. Nucleic Acids Res. 2000, 28, 3442-3444. [CrossRef] [PubMed] 
24. Szklarczyk, D.; Gable, A.L.; Lyon, D.; Junge, A.; Wyder, S.; Huerta-Cepas, J.; Simonovic, M.; Doncheva, N.T.; Morris, J.H.; Bork, P.; et al. String v11: Protein-Protein association networks with increased coverage, supporting functional discovery in genome-wide experimental datasets. Nucleic Acids Res. 2019, 47, D607-D613. [CrossRef] [PubMed]

25. La Rosa, R.; Rossi, E.; Feist, A.M.; Johansen, H.K.; Molin, S. Compensatory evolution of Pseudomonas aeruginosa's slow growth phenotype suggests mechanisms of adaptation in cystic fibrosis. Nat. Commun. 2021, 12, 3186. [CrossRef] [PubMed]

26. Ziha-Zarifi, I.; Llanes, C.; Köhler, T.; Pechere, J.-C.; Plesiat, P. In Vivo emergence of multidrug-resistant mutants of Pseudomonas aeruginosa overexpressing the active efflux system MexA-MexB-OprM. Antimicrob. Agents Chemother. 1999, 43, 287-291. [CrossRef]

27. Doi, Y.; Arakawa, Y. $16 \mathrm{~S}$ ribosomal RNA methylation: Emerging resistance mechanism against aminoglycosides. Clin. Infect. Dis. 2007, 45, 88-94. [CrossRef]

28. Mikheil, D.M.; Shippy, D.; Eakley, N.M.; Okwumabua, O.E.; Fadl, A.A. Deletion of gene encoding methyltransferase (gidB) confers high-level antimicrobial resistance in Salmonella. J. Antibiot. 2012, 65, 185-192. [CrossRef]

29. Shippy, D.; Fadl, A.A. RNA modification enzymes encoded by the gid operon: Implications in biology and virulence of bacteria. Microb. Pathog. 2015, 89, 100-107. [CrossRef]

30. Yu, S.; Wei, Q.; Zhao, T.; Guo, Y.; Ma, L.Z. A Survival Strategy for Pseudomonas aeruginosa that uses exopolysaccharides to sequester and store iron to stimulate psl-dependent biofilm formation. Appl. Environ. Microbiol. 2016, 82, 6403-6413. [CrossRef] [PubMed]

31. Menendez, A.; Finlay, B.B. Defensins in the immunology of bacterial infections. Curr. Opin. Immunol. 2007, 19, 385-391. [CrossRef]

32. Li, Y.-H.; Tian, X. Quorum sensing and bacterial social interactions in biofilms. Sensors 2012, 12, 2519-2538. [CrossRef] [PubMed]

33. Ciofu, O.; Tolker-Nielsen, T. Tolerance and resistance of Pseudomonas aeruginosa biofilms to antimicrobial agents- How P. aeruginosa can escape antibiotics. Front. Microbiol. 2019, 10, 913. [CrossRef] [PubMed]

34. Schiller, N.L.; Monday, S.R.; Boyd, C.M.; Keen, N.T.; Ohman, D.E. Characterization of the Pseudomonas aeruginosa alginate lyase gene (algL): Cloning, sequencing, and expression in Escherichia coli. J. Bacteriol. 1993, 175, 4780-4789. [CrossRef]

35. Deretic, V.; Konyecsni, W.M. Control of mucoidy in Pseudomonas aeruginosa: Transcriptional regulation of algR and identification of the second regulatory gene, algQ. J. Bacteriol. 1989, 171, 3680-3688. [CrossRef] [PubMed]

36. Jackson, K.D.; Starkey, M.; Kremer, S.; Parsek, M.R.; Wozniak, D.J. Identification of psl, a locus encoding a potential exopolysaccharide that is essential for Pseudomonas aeruginosa PAO1 biofilm formation. J. Bacteriol. 2004, 186, 4466-4475. [CrossRef] [PubMed]

37. Qiu, D.; Eisinger, V.M.; Rowen, D.W.; Yu, H.D. Regulated proteolysis controls mucoid conversion in Pseudomonas aeruginosa. Proc. Natl. Acad. Sci. USA 2007, 104, 8107-8112. [CrossRef]

38. Kim, Y.; Wood, T.K. Toxins Hha and CspD and small RNA regulator Hfq are involved in persister cell formation through MqsR in Escherichia coli. Biochem. Biophys. Res. Commun. 2010, 391, 209-213. [CrossRef] [PubMed]

39. Korotkov, K.; Sandkvist, M.; Hol, W.G.J. The type II secretion system: Biogenesis, molecular architecture and mechanism. Nat. Rev. Genet. 2012, 10, 336-351. [CrossRef]

40. Ma, Q.; Zhai, Y.; Schneider, J.C.; Ramseier, T.M.; Saier, M.H. Protein secretion systems of Pseudomonas aeruginosa and P. fluorescens. Biochim. Biophys. Acta Biomembr. 2003, 1611, 223-233. [CrossRef]

41. Notti, R.Q.; Stebbins, C.E. The structure and function of type III secretion systems. Microbiol. Spectr. 2016, 4. [CrossRef] [PubMed]

42. Sandoval-Motta, S.; Aldana, M. Adaptive resistance to antibiotics in bacteria: A systems biology perspective. Wiley Interdiscip. Rev. Syst. Biol. Med. 2016, 8, 253-267. [CrossRef] [PubMed] 